\title{
KRAASNA NOMINAL DERIVATION
}

\author{
Enn Ernits \\ Estonian University of Life Sciences, EE \\ enn.ernits@emu.ee
}

\begin{abstract}
This article examines the derivation of Kraasna nominals using suffixes. Despite limited documentation, it was possible to find a large number of nominal derivatives using 18 derivational suffixes formed from 20 primary suffixes and 21 suffixes formed from 21 secondary suffixes. Kraasna suffixes mostly resemble those of Seto. Only the compound suffixes $(-i) s$-to, $-l a-s$, and -ži-ne, which derive just a few words (kaklas, laanist, soomist, ammuužine) are not characteristic of Seto. The suffixes *-ek

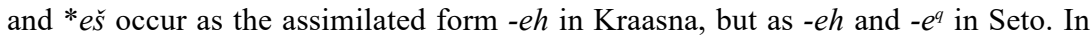
oblique cases, the derivational suffix -eh still occurs in a mid-19th century folk song but had been lost by the early 20 th century. The Kraasna dialect is surprisingly similar to Seto, from which it separated 300 years before its documentation in the early 20 th century. It would be interesting to know to what extent later connections with Setomaa harmonised both dialects.
\end{abstract}

Keywords: morphology, nominals, derivatives, Finnic languages, Estonian, South Estonian, Seto, Kraasna

DOI: https://doi.org/10.12697/jeful.2021.12.2.12

\section{Introduction}

The Kraasna dialect became extinct in the early 20th century and the Kraasna community is now fully assimilated into the Russians. The ancestors of the Kraasna community came from nearby eastern Setomaa and settled near the small town of Krasny (now called Krasnogorodsk) near Opochka in Pskov District in the late 16th or early 17th century (Mets et al. 2014: 14, Pajusalu 2020: 200).

The first records of the Kraasna community date to 1849 . These were sent to Friedrich Reinhold Kreutzwald (1803-1882), the compiler of the epic "Kalevipoeg", who at the time was assisting the head of the statistical department of the Russian Geographical Society Peter v. Koeppen (1793-1864) in the compilation of a population map of 
European Russia by Adolph Johann Brandt (1812-1856) who was employed there. The latter sent to Kreutzwald four folk songs written down by a non-Estonian-speaking lady, in a form which was, however, rather flawed and distorted (see Ernits 2012: 42-48). Several attempts have been made to reconstruct the texts, translate them into German and Estonian, and publish them; most recently by the author of the present article (Ernits 2018; see also Neus 1852).

The first study of Kraasna language and culture was compiled and published in 1903 by Estonian folklore researcher Oskar Kallas (1868-1946). This overview contains 23 folk song texts and excerpts, proverbs, folk tales, etc. (Kallas 1903). His documentation is considerably more precise than that of his predecessors, though it still contains minor omissions and inconsistencies, e.g., the marking of the laryngeal stop and back-e.

In the early 1910s, Finnish linguist Heikki Ojansuu (1873-1923) documented the Kraasna dialect more broadly prior to its extinction. His documentation, copies of which were given to the Academic Mother Tongue Society (Akadeemiline Emakeele Selts) in 1937 and 1938 by the Finnish Literature Society (Suomalaisen Kirjallisuuden Seura), was published in the final volume of the Estonian dialect text series "Eesti murded" (Mets et al. 2014: 277-294, No. 186-207; see also p. 7). Though Kraasna was visited after 1940, it was no longer possible to collect any significant language material. In 2016, Tobias Weber, then a student at the University of Munich, wrote a comprehensive bachelor's thesis (and later also a master's thesis) on the Kraasna dialect, in which he also published the handwritten notes of Kallas and Ojansuu comparing them linguistically with each other and with those published in Mets et al. (2014). In general, Kraasna language documentation is rather limited. Its research history is more thoroughly described in Weber (2016: 1 ff.; Weber 2018: 9 and others). Word formation has not yet been studied.

\section{Materials and methods}

Relatively few derivational suffixes of nominal words in Võro South Estonian have been studied (cf. Käsi 2000: 173). The current article deals with Kraasna nominal derivation by means of suffixation. Nouns and adjectives are discussed separately, which are formed either using primary (simple) or secondary (compound) suffixation, or from nominals 
or verbs using denominalising or deverbalising suffixes, respectively. Native words and loans are distinguished; in the latter case, a distinction is made between whether the entire word is a loan or just the root. Efforts have been made to use relevant vocabulary as much as possible, and it is presented alphabetically for each suffix. With respect to word formation, the views of Erelt, Erelt \& Ross (2020) and Kasik (2015) have been taken into account. The following works have been especially helpful with respect to historical linguistic questions: Hakulinen (1968), Laanest (1975), Mägiste (1982-1983), and Metsmägi, Sedrik $\&$ Soosaar (2012). Due to limitations on space, several types of derivatives are not examined in this article including some vowel-final derivatives, which have lost their endings in the nominative singular as well as $i$-derivatives, e.g., pini 'dog' (Est V: 1942; < *penä, Hakulinen 1968: 104). Likewise unexamined are late loan derivatives with suffixes of foreign origin, e.g., $t^{\prime} i e d-a$ 'grandfather; old man' (Mets et al. 2014:

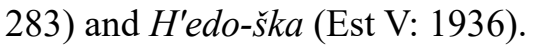

Examples are presented in a simplified Seto script. For the sake of simplicity and consistency, in reconstructions as well as in examples taken from written records, the laryngeal stop is written as ${ }^{q}$ and back-e as $\tilde{o}$. The latter in the word forms documented by Kallas is not restored in the examples. Phonetically reconstructed word forms are marked with an asterisk. Due to the scarcity of documented Kraasna vocabulary, the nominative singular form of the word is often missing. In such cases, a theoretical form is reconstructed alongside an attested form in a different noun case and, if possible, on the basis of a similar word in the South Estonian Seto dialect. Often the meaning of a word is not known, in which case this is derived based on Seto logic. Theoretical reconstructed word meanings are marked with ${ }^{+}$. It should be noted that any reconstruction is still to a greater or lesser extent somewhat approximate (and primarily assisted by Haak et al. 1994-2020, Käsi 2016, Saar et al. 2020, Pall 1982-1989, and Käsi 2011). Word forms found in a different noun case are given with abbreviations for their case and number. The semantics of suffix and nominal derivation are also not ignored.

Usually, the page number of published sources or manuscripts is referenced in the article. Folk songs are the exception, as the number in front of the hyphen marks the song number and the one behind it marks the verse number. When using the folk songs sent by Brandt, their 
number and the verse number (by colony) are referenced according to Ernits 2018. The source of the manuscript material is Weber (2016).

\section{Primary nominal derivatives}

-dze- -dzõ- < -nE : -dzE. NomPl *sõzaridzõ ${ }^{q}$ 'sisters' (Kallas 1903: 124; Se sõsaridse ${ }^{q}<$ sõsar' 'sister'); NomPl vaderidze ${ }^{q}$ 'godparents' (Mets et al. 2014: 291; Se vatõr' 'godparent'); NomPl velidze $e^{q}$ 'brothers' (AES 202: 11; Se velidse $e^{q}<$ veli 'brother'). This suffix is abstracted from the ne-suffix (see below), a diminutive or collective suffix denoting a group of people, cf. Leivu ilženidze[ $\left.{ }^{q}\right]$ 'Ilzene residents' (Faster 2015: 269). The latter is only used in the plural.

-du $\sim$-dü $\sim$-tu $\sim$-tü < *-toin. The adjectives ilmadu 'huge, very much' (AES 202: 10; cf. Se ilmadu < ilm 'weather; world') and 'ilotu 'unpleasant; ugly; inappropriate, unbefitting' (PrtSg ilotust; Kallas 1903: 13-3...4; cf. Se ilodu ilodo < ilo 'beauty; joy', Univere 1972: 164) are formed using this denominal suffix indicating the absence of a property. See also $-d-u s \sim-d$ - $u s$.

-eh $\sim$ - $\mathbf{o h}:-\mathbf{e} \sim-\tilde{\mathbf{o}}<*$-Ek ja *-Ěs. This can be both a denominal and a deverbal suffix. In the Kraasna dialect, two historical suffixes have converged resulting in the same $h$-final result. The root words containing the suffix *-ěs are mostly unknown (Laanest 1975: 133). Nominal derivatives include ${ }^{+}$hoonõ 'building' (NomP1 huunõ ${ }^{q}$, AES 202: 12; cf. Se hoonõh $\sim$ hoonõ $\tilde{q}^{q}$ ); imeh jimme 'miracle' (Est V: 1938; AES 202: 21; Se imeh $\sim$ ime ${ }^{q}$ ); murõh 'sorrow' (Est V: 1945); ${ }^{+}$palõh 'cheek; face' (Haak et al. 1994-2020; Se palõ $\sim$ palõ $)$; pereh $\sim$ perreh 'family' (AES 202: 13; Est V: 1934; cf. Se pereh $\sim$ pere $^{q}$; < perä 'base; back; remainder', see Metsmägi, Sedrik \& Soosaar 2012 sub pere); perzeh 'buttocks' (NomPl pierze $e^{q}$, Mets et al. 2014: 290; AES 202; cf. Se perä, see Metsmägi, Sedrik \& Soosaar 2012 sub perse); tarõ 'room' (Mets et al. 2014: 281; see Metsmägi, Sedrik \& Soosaar 2012 sub tare); 'undsõh 'fog' (undzeh, Est V: 1946; Se unds õ $)$.

It is unclear whether some words are original words or Baltic or Germanic loans, cf. ${ }^{+}$hoonõh and blt *šānas; ${ }^{+}$palõ $h$ and Proto-Germanic *balgiz, tarõ and ruO dorŭ or germL dare (for possible native words see Metsmägi, Sedrik \& Soosaar 2012 sub tare). hammõh 'shirt' (Est V: 1935) is a loanword, Proto-Germanic * $\chi a m i-z ;$ Metsmägi, Sedrik 
\& Soosaar 2012). If this word pair is correctly recorded, then it also belongs here: *toorõ $(h)$ : *tuurõ 'raw, fresh' (tuore : ElaSg or TraSg tuurest (Est V: 1940, 1947; cf. Se tooras toorõss : tuurõ, but fi tuore).

Deverbals show objects of actions: kastõh 'dew' (Est V: 1941; cf. et kastma 'to water, irrigate'); lihavõedeh 'Easter, lit. meat taking' (Est V: 1953; see et võtma 'to take'); ${ }^{+} m a ̈ h e^{q}:$ mähke? 'diaper' (IllP1? mähkühe, AES 202: 14; but Se mähe : mähkmä; cf. et mähkima 'to wrap') and paaz'ôh 'abscess' (PrtPl paižit; Est V: 1952; cf. et paisuma 'to swell' or paistma 'to shine').

-e $\sim-\tilde{\mathbf{o}}<*$-Ea $<*$-EtA. The following adjectives of Proto-Finnic origin or older are formed using denominal -e: haigõ 'ill' (AES 202: 11); helde 'generous' (Kallas 1903: 91; cf. hell 'tender; sensitive; sore'); jämme 'thick' (GenSg jämmee, AES 202: 13); kangõ 'stiff; strong' (Est V: 1945; cf. kang 'crow-bar'); korgõ 'high' (Mets et al. 2014: 291; IllSg kuorgõhõ, AES 202: 26); 'lipõ 'slippery' (PrtSg libõhõt; Mets et al. 2014: 281); pehme 'soft' (AES 202: 9); ${ }^{+}$pümme 'dark' (GenSg? pümmee, AES 202); rassõ 'heavy' (AES 202: 9); sakõ 'frequent' (AES 202: 7); terveh 'healthy' (Est V: 1937; SgEss tervehnä (AES 202: 9); tihkõ 'dense' (Est V: 1945); valgõ 'white' (Est V: 1934). Helde is a variant formed by analogy to a consonant gradational stem (Metsmägi, Sedrik \& Soosaar 2012). Tere (AES 202: 28) is based on the shape of the word terveh. The derivational suffix - $\tilde{h}$ appears in other cases in folk song variants documented in the mid-19th century, later it disappears, cf. *valgõhõta (PrtSg walga heta, Br: 1-2) valgõt (Mets et al. 2014: 288) valgõta (Kallas 1903: 1-3; all three words PrtSg). This group may also include NomPl ${ }^{+} p u h t \tilde{o}^{q}$ 'funeral' (AllPl puhtilõ, Est V: 1945; Se puhtõ ${ }^{q}$; cf. et puhe 'dawn'; originally 'a funeral feast held in the morning', Mägiste 1982-1983: 2200).

-i : - ja $\sim-\mathbf{j a ̈}<*$-jA. Two plant names are formed using the denominal jV-suffix: katai : kadaja 'juniper' (AES 202: 10; ERA II: 94; cf. Se katai : kadaja) and petäi 'pine' (Est V: 1934) : ${ }^{+}$pedäjä (NomPl pedäjäq, AES 202: 3), also likely is ${ }^{+}$putsai 'feather' (NomPl pudzajaq, Est V: 1938; Se putsai : pudsaja; cf. puts : pudsu 'fluff' (Mägiste 1982-1983: 2255), the same as et $p u d i$ and $p u d u$. Probably also of the same origin is kevväi : ${ }^{+k e v a ̈ j a ̈ ~ ' s p r i n g ' ~(E s t ~ V: ~ 1944 ; ~ A b l S g ~ k e v a ̈ j a ̈ l t, ~ A E S ~ 202: ~ 11) ~ a n d ~}$ min'n'i 'daughter-in-law' (NomPl minijäa, AES 202: 12; Est V: 1949; cf. however Mägiste 1982-1983: 1540: < minema 'to go' + doer -ja $-j \ddot{a})$. The word $m \tilde{o} r^{\prime} z$ 'ja 'bride' is not included among Baltic loans here 
(cf. Proto-Baltic *martjā, Mägiste 1982-1983: 1601). ${ }^{1}$ This denominal suffix is considered to be based on the original form $*_{-} k a \sim *_{-k} a \ddot{a}$ (Laanest 1975: 136), but it is possible that other suffixes have been joined to this stem in other languages and dialects.

In contrast, significantly more nouns are formed using the deverbal $j V$-suffix. Nouns describing doers include thaudja 'steamer' (AllSg viha haudjallõ 'bath whisk steamer', Mets et al. 2014: 290; cf. Se haudma 'to steam'); 'kandija 'carrier' (TraSg adra kandias 'plough carrier', Br: 4-7; cf. kandma 'carry'); *kodohoidja 'one who looks after the house when others are not at home', lit. 'housekeeper' (kodohoiidja, Kallas 1903: 98); ${ }^{+k u ̈ l b i j a ̈ ~ ' s o w e r ' ~(T r a S g ~ k u ̈ l b i a s, ~ B r: ~ 4-6 ; ~ c f . ~ S e ~ k u ̈ l b m a ̈ ~}$ 'to sow'); 'kütjä 'heater' (AllSg sanna kütjäle 'sauna heater'; Mets et al. 2014: 290); 'laulja 'singer' (NomPl hähilaulja ' 'wedding singer', Est V: 1935; cf. laulma 'to sing'); 'tuuja 'bringer' (AllSg vii tuujallõ 'water bringer'; Mets et al. 2014: 290); 'vingjä 'whiner' (AdeSg vingjäl; Mets et al. 2014: 290); 'võttija 'taker' (TraSg witze wätias 'whipper', Br: 4-5). In two cases, this deverbal formation has secondarily resulted in animal meanings: elläi 'animal' (Est V: 1947; cf. Se elläi : eläjä < elämä 'live') $)^{2}$ and 'sü̈̈̈ä 'parasite' (PrtSg sööjaid, Kallas 1903: 97; cf. Se sü̈̈ma 'to eat'). A couple of lexemes refer to tools: rapai 'swingle (a sword-like instrument with a wide wooden blade used with flax stalks; et ropsimõók)' (Est V: 1940; cf. Se rapai : rabaja and rabahhamma: rapa ${ }^{q}$ also: 'to thresh flax') as well as var'okaaja 'mirror', lit. 'shadow watcher' (Est V: 1942; cf. Se var'okaetus 'mirror'); in one case also an important event NomPl saaja ${ }^{q}$ 'wedding' (AES 202: 2; Se saaja ${ }^{q} \sim$ saja $^{q}<$ saama 'to get', Metsmägi, Sedrik \& Soosaar 2012). An unknown meaning is encountered in üllei : ülejä (Est V: 1951).

-k : - $\mathbf{g a}<*-\mathbf{k} \mathbf{k A}$. The study of words with this suffix poses several problems: 1) most words do not have a documented singular genitive form, making it difficult to distinguish words formed with the com-

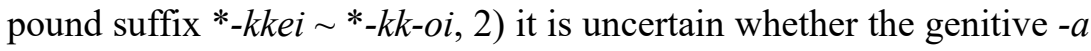
or $-u$ ending is not due to analogy, 3) a variety of $k$-suffixes has been observed in Estonian dialects (Neetar 1990: 49). Therefore, words with both suffixes are discussed together. Additionally, due to apocope in the

1 The suffix - $n$ : -me- in Fi morsian : morsiamen 'bride' is secondary (see Hakulinen 1968: 112).

2 cf. suur elläi $\sim$ suur jelläi 'rich man' (Kallas 1903: 27). 
nominative, there is also a third $k$-type secondary derivational suffix (see Section 4).

This Kraasna denominal suffix forms the following noun and adjective derivatives: ${ }^{+}$(huu)hublik 'sorrel, lit. horse sorrel (Rumex crispus)' (NomPl (huu)hubliga , AES 202: 5; cf. et huba 'crumbly', Metsmägi, Sedrik \& Soosaar 2012; lut'k '(bed)bug' (Est V: 1940); maas'k 'strawberry' (Est V: 1934; presumably, the same stem as the word manner 'mainland', Metsmägi, Sedrik \& Soosaar 2012); mus't'k '(black) bilberry' (Est V: 1934; cf. must 'black'); or'k orik (78); uor'k 'boar' (Est V: 1942; Kallas 1903: 32, 78; eS word; GenSg is oriku, Käsi 2011; which derives from the word ora 'spike, bodkin' or Proto-Germanic, Metsmägi, Sedrik \& Soosaar 2012); ${ }^{+}$sit'k sitik 'black currant' (NomPl sitka $a^{q}$, AES 202: 7; Se sitikmar'a $a^{q} \sim$ sitka $a^{q}$ rr' $^{q}{ }^{q}<$ sitik 'beetle' < sitt 'shit'); suolik 'intestine' (NomPl suoligu $u^{q} \sim$ suoligó $^{q}$, AES 202: 7; Est V: 1934; cf. fi suoli); vas'k' 'calf' (Est V: 1949; cf. vasik $\sim$ vas'k); cf. Proto-Indo-Iranian vasa-). This suffix derives animal as well as plant names. The word harak 'magpie' (NomPl haragu', AES 202: 10Est V: 1938) is a Baltic loan, while ${ }^{+} k a s u k(-k<$ ru $-h)$ 'fur coat' and turak $(-\mathrm{k}<\mathrm{ru}-k)$ 'fool' (Pall 1982-1989) are Russian loans (Metsmägi, Sedrik $\&$ Soosaar 2012) as well as kill'ok 'clay hand washing dish' (cf. Se kilok : kiloga, kilokas < ru гилек).

-l' : -la- <*-IA. Nouns are formed using this denominal suffix jummal $\sim$ jimmal (AES 202: 7, 11; the vowel $i$ in jimmal was pronounced backwards; cf. Se jummal') : jumala jimala 'god' (Kallas 1903: 65; AES 202: 11) and pässül 'steelyard (et päsmer, margapuu)' (AES 202: 11; Se pässül' : päsülä). The suffix is attached to the first part of the germL besemer $\sim$ besmer $\sim$ bisemer, cf. also pässerm (Metsmägi, Sedrik \& Soosaar 2012). An assumed Baltic loanword is sammõl : samble 'moss' (Est V: 1952; NomPl samblö ${ }^{q}$, Est V: 1938); Proto-Baltic $n$ was replaced by Finnic $l$ (cf. blt * samanas), and of Proto-Germanic origin is ${ }^{+}$hummal' 'hops' (NomPl humala , ERA II: 106). The only known adjective is matal : madala 'low' (AES 202: 4; Mets et al. 2014: 291).

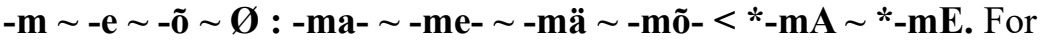
various reasons, three related Finnic suffixes have assimilated in the Kraasna dialect. Descendants of these are, for example: fi -in, $-m a \sim-m \ddot{a}$

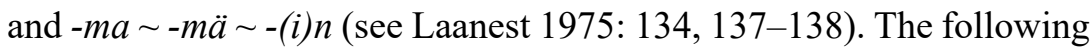
are denominal derivatives: ${ }^{+}{ }^{2}$ kim? ' (tooth) gums' (AES 202: 4; NomP1 igime ${ }^{q}$, Est V: 1934; Se ikim : igime; cf. fi ien : ikene-); ${ }^{+}$süä 'heart' 
(AdeSg süämel; Kallas 1903: 91, 92; cf. fi sydäin); ${ }^{+}$tukõm 'support?' (AllSg tugemile, Kallas 1903: 1-23; cf. eS tugim tukim 'switch, rod', tugimus 'cudgel; sprig', Wiedemann 1973: 1211; cf. Se tugi 'support') and võezi võizi : võiz'me 'butter' (Est V: 1947; Kallas 1903: 86; Mets et al. 2014: 287; Se puuvõisi : puuvõisma : puuvõismõ 'vegetable oil'; *voisime- <*voitime <*voit[a]-ime (Mägiste 1982-1983: 3936). In some words, the singular nominative $-m$ has survived due to the influence of the genitive.

Of adjectival origin is nõdrm: nõdr'me $\sim$ ?nõdorrna 'cradle pole; a device for pressing grain into a mortar' (AES 202: 8; Haak et al. 1994-2020; Est V: 1937; -na <*-ma; Se nõdõrm : nõdõrma $\sim$ nõdõrmõ $<$ nõdõr, cf. et nõder 'weak; (dialect form:) cradle spar', in related languages also: 'flexible', Metsmägi, Sedrik \& Soosaar 2012) ${ }^{3}$ and NomP1 suurma ${ }^{q}$ 'groats' (AES 202: 25; Se suurma ${ }^{q}<$ suur' 'large', see Mägiste 1982-1983: 2941). ${ }^{4}$ The other derivative type is häijerm (see Sec. 4).

The deverbal derivatives are ${ }^{+} a z \tilde{o}$ 'location; sleeping place' (NomP1 azõmõ , AES 202: 6; Se as õ : asõma $\sim$ asõmõ < asuma 'to come into being, to appear' < asuma 'to dwell; to be located'); võti 'key' (NomP1 võtmõ , AES 202: 20; cf. Se võtma 'to take'); NomPl vuulme ' 'drawknife' (Kallas 1903: 25); cf. Se vuul'ma 'to whittle', see Metsmägi, Sedrik \& Soosaar 2012). The known Kraasna partitive singular form of this suffix is -nd, e.g., azõnd 'place' (Mets et al. 2014: 280; also Se asõnd) and võezind 'butter' (Mets et al. 2014: 283).

-n : -na $\sim$-nä < *-nA. This denominal suffix appears in the words hapõn : habõna 'beard' (Est V: 1937), which is commonly used in its plural form habõna ${ }^{q}$ (AES 202: 4; cf. Se habõna ${ }^{q}$ ), and 'upin 'apple' (NomPl ubina ${ }^{q}$, AES 202: 25; cf. Se upin < uba 'bean', see Metsmägi, Sedrik \& Soosaar 2012). A deverbal suffix of the same form is found in adjectives ${ }^{+}$kas'sin : kazina 'scanty; clean' (AllSg kazinale, Kallas 1903: 14-11; Se kassin < kasima : kassi ${ }^{q}$ 'to clean; to harvest fruit') where the suffix indicates a diminutive (Mägiste 1982-1983: 722; Neetar 1990: 85 does not address the derivative).

3 The South Estonian word has become $a$-final only in the Võnnu and Seto varieties, elsewhere it is $u$-type (see Haak et al. 1994-2020). This is why Mägiste only allows for a $m u$-suffix (<*-moi; Mägiste 1982-1983: 1756).

4 Fi suurima $\sim$ suurimo 'an individual grain or groat' is indirectly associated with a verb known from folk songs suurtaa 'to break into individual grains or groats' (Hakulinen 1968: 162). 
-nd $\sim$-d $<*$-ntA. This denominal suffix usually means 'with something or someone similar', e.g., 'imänd $\sim$ *jimänd 'lady' (NomPl imänd $\ddot{a ̈}^{q}$, Kallas 1903: 6-33; Est V: 1936; Se imä 'mother'); Essänd : Essändä 'Lord' (Est V: 1949; AllSg Essändäle AES 202: 12); ezänd +jezänd : ezändä jezändä 'gentleman; manor lord' (Kallas 1903: 96, 98; AES 202: 3; Se esä); soend 'werewolf' (Kallas 1903: 96; also Se soend < susi : soe 'wolf'). The shape of this suffix (-nd $>-d)$ is unique: põrmad : põrmadu 'floor' (Est V: 1934, 1943. Word forms found in Kallas: põrmandul (Kallas 1903: 124) and põrmandule (ERA I: 26); cf. also Se põrmad $\sim$ põrmand : põrmadu $\sim$ põrmandu). These are probably constructed by analogy.

-ne $\sim$-nõ : -ze $\sim$-zõ or -dze $\sim$-dzõ $<*$-(i)nEn : -*(i)sE- $\sim$-*(i) tsE- $<*^{*}-\mathbf{n}^{\prime} \mathbf{c}^{\prime} \mathbf{E}$ (see also $n^{\prime}$ ). This denominal suffix forms nouns as well as adjectives. Some nouns are abstracted from adjectives. Some words do not have singular forms. Referring to means of action: NomPl ahersälüze $e^{q}$ 'breeching (a part of a horse harness)' (Est V: 1940; still only in Se and Vas); NomPl pädze $\sim$ päädze 'headstall, halter' (Est V: 1934, 1940; Se päitse < päine : päitse < pää 'head') and suudzõ 'bridle' (Est V: 1934; < suu 'mouth'). Referring to people in general, relatives, etc.: in'imen'e : inimize 'human; person' (Mets et al. 2014: 277; AES 202: 25); kabõhañ̃ kabõhõnõ 'young woman' (NomPl kabõhõdze $e^{q}$ AES 202: 12, 28; Kallas 1903: 40; -he -hõ is a suffix on the base word; Se kabõhhõnõ); naan'õ : naaz'õ 'woman, wife' (Mets et al. 2014: 280; Est V: 1938); sulanõ 'hind, farmhand' (AES 202: 10; cf. fi sulhanen 'bridegroom'; < sula 'gentle', Mägiste 1982-1983: 2908). Referring to members of the animal kingdom: ${ }^{+}$mehine 'bee' (NomPl mehidze ${ }^{q}$, Est V: 1950; Se mehine : mehidse) and 'tianõ 'titmouse' (tiazehain, Kallas 1903: 45). The secondary variant of this suffix is the denominal $-n^{\prime}:-z e \sim-z \tilde{o}$, which occurs in the nouns hopõn' $:$ hobozzo 'horse' and repän' 'fox' (both Est V: 1934). Referring to holidays or activities: ristjäts 'baptism' (Mets et al. 2014: 277; Se plural ristjätsi ${ }^{q}$ ); NomPl talidze $e^{q}$ 'Christmas' (AES 202: 6) (see also adjectives) and ö̈tsi 'grazing of horses at night' (AES 202: 20; Se öüts : ö̈dsi < öine : öise $\sim$ öitse < öö 'night'). Not grouped by meaning: laudadze $e^{q} \sim$ laadadze[ [q] 'an offering made to the cowhouse gods; et lehmäkahi' (Kallas 1903: 86; cf. Se laut : lauda 'cowshed'); NomPl päälze [ $\left.{ }^{q}\right]$ 'haulms' (Est V: 1940) and tarõalunõ 'basement (lit. 'under the room or house') (Kallas 1903: 26; Se tarõalonõ). See also -dze- -dzõ-. 
There is an abundance of adjectives derived from nouns: haavane 'of aspen (wood)' (haavane; AES 202: 25); jä̈̈ne 'icy, covered with ice' (Kallas 1903: 126); kadajanõ 'of juniper' (Est V: 1952); ${ }^{+} k u l l a n \tilde{~}$ 'golden, of gold' (GenPl kulladzide, Kallas 1903: 6-51...54; cf. Se kullanõ); kõllanõ 'yellow' (AES 202: 11); kõonõ kõõvunõ 'of birch (wood)' (AES 202: 25; Est V: 1952; < kõiv : kõo 'birch'); külmäne 'cold' (Mets et al. 2014: 290); lepäne 'of alder (wood)' (AES 202: 25); näl'äne 'hungry' (Est V: 1944); paiunõ (Haak et al. 1994-2020) 'of willow (wood)' (NomPl pajudz $\tilde{o}^{q}$, Est V: 1941); patane 'sinful' (AllPl patadzile, Kallas 1903: 100; Se patanõ < patt : patu 'sin'; plural stem, Käsi 2000: 173); ${ }^{+}$pedäjine 'of pine' (NomPl pedäjidzeq , AES 202: 25; cf. Se petäi); puzanõ 'bitter' (Est V: 1953; only in Kra; cf. also Kra pusa 'sullen'?); puunõ 'wooden, of wood' (Est V: 1940) (ElaSg puudzest, Kallas 1903: 88); ravvanõ 'made of iron' (AES 202: 8); with unclear meanings: 'sadõhinõ : sadõhitse 'rainy?' (Mets et al. 2014: 290; may be a derivative of the word *sadõh, but it has not been documented, cf. still in Se sado 'precipitation; rotten wood; lazy person'); savino 'clayey' (NomPl savidz $\tilde{o}^{q}$, Est V: 1953; AES 202: 13); sinine šinine 'blue' (Est V: 1941, 1951; NomP1 sinidze $e^{q}$ AES 202: 12); sitanõ 'mucky' (AES 202: 21); suvidz ö pühiq 'Pentecost' (suvidze' pühi', Kallas 1903: 44); tal'ize pühi' tal'zi pühi 'Christmas' (Kallas 1903: 44; Mets et al. 2014: 282; Se tal'sipühi < *talvinõ : *talvidzõ 'wintery'); 'teräne 'of steel' (GenPl terädzide, Kallas 1903: 6-51...54; cf. terane 'steel', Pall 1982-1989); *tõbinõ 'ill' (tõpine, Kallas 1903: 5-5); ${ }^{+}$tõrvanõ 'tarry' in the compound tõrvashain (Kallas 1903: 45); ${ }^{+}$utonõ? 'foggy' (NomPl utoza ${ }^{q}$, Est V: 1940); 'vaenõ 'poor' (vaenegi, Est V: 1940; < *vaivainen 'miserable; difficult' < vaiv, Metsmägi, Sedrik \& Soosaar 2012); vahanõ 'waxy, of wax' (AES 202: 11); ${ }^{+}$vas'no 'copper, of copper' (GenPl vas'tside, Kallas 1903: 6-51...54; cf. Se vasinõ <*vas'k 'copper'); vastanõ 'new' (Est $\mathrm{V}: 1938) ;{ }^{+}$ves'ne 'watery, wet' (IneSg ves'tseh, AES 202: 25); ${ }^{+}$vihano 'angry' (NomPl vihaza $a^{q}$ AES 202: 12).

The adjectives haavanõ, lepäne, ravvanõ, etc. refer to materials; this is characteristic of the Võro dialect (Käsi 2000: 173; see also Viires 1960: 50-51). The $p$-sound in *tõbinõ is either an inaccuracy or hypercorrection, cf. regular in Võro tõbinõ tõpin 'ill' (Käsi 2011: 790).

5 It is possible it is also derived from a noun with a suffix, cf. Se tõrvas 'pitch pine' $(<$ tõrv 'tar') . 
Words of adverbial origin indicate time: 'hummõnõnõ 'of tomorrow' (GenSg hummenetse; AES 202: 25; < the adverb 'hummonn' 'tomorrow'); muistine 'ancient' (Kallas 1903: 71; < тии 'another', Mägiste 1982-1983: 1563); ${ }^{+}$vahtnõ : vahtsõ 'new' (Mets et al. 2014: 285; < vas't 'maybe', Metsmägi, Sedrik \& Soosaar 2012).

-o $\sim$-u $<*_{-0}$. Initially, Kra $-o\left(<*_{-} o\right.$ and $*_{-o i}$, see also Sec. 4) and *-u were three different suffixes, the use of which is quite varied in South Estonian language varieties due to the $o>u$ change (see Kettunen 1929: $155-156,157-159)$. Originally derived by deverbal $-o$ are the nouns elo $\sim$ jelo 'dwelling house' (Kallas 1903: 90; Mets et al. 2014: 290; cf. Se elo 'life; household' < elämä 'to live'); ${ }^{+k i i r d}$ 'winding?' (ComSg kieruga, Est V: 1949; cf. Se kiird 'winding', kiirdmä 'to wind', cf. fi kierto); and teno 'thanks' (Kallas 1903: 14-5, 6; cf. fi tenho 'enchantment; witchcraft', Se teno and tehnämä 'to thank').

$\mathbf{- o} \sim-\mathbf{u}<*$-u. Originally, the noun ${ }^{+} k a h r$ 'bear' had the $u$-suffix (NomPl kahru $\sim$ kahrõ $\tilde{o}^{q}$, AES 202: 10, Est V: 1950; Se kahr : kahro; probably the same stem as the word kare 'rough', Metsmägi, Sedrik \& Soosaar 2012), 'mago : mao 'taste, flavour' (mako, Kallas 1903: 100; cf. Se magu: mau : maku) and pago 'block' (viizupago 'bast shoe block' (Est V: 1941; cf. Se pago : pao '(boot) last'); the main component of this compound word is considered to be a variant of the lexeme pakk: paku 'block; chunk', assuming the Finnic alternation *-k- * *-kk- (Mägiste 1982-1983: 1904). ${ }^{6}$

-r : -ra $\sim$-re $\sim$-rõ $<*$-rA. With this suffix the following are formed: $k \tilde{d} r \sim k \tilde{d} \tilde{r}:$ kõdra 'seed pod' (Est V: 1943, 1951; probably the same stem as in the Finnish word kotelo 'casing, shell; cocoon', Metsmägi, Sedrik \& Soosaar 2012) and the first component of the compound word künnärpää 'elbow' (Est V: 1934) (cf. Lut künnärpää, Se künnär'pää) and 'pinnär' 'planting bed' (NomPl pindreq ${ }^{q}$ Est V: 1936; Se pinnär'). The remaining words are mainly loans from Indo-European languages borrowed at various times: ${ }^{+} k \tilde{t} t a r$ ' wheel spoke' (NomPl kõdara ${ }^{q}$, Est V: 1940); ' sõbõr 'friend' (ComSg sõbraga, AES 202: 7); 'sõzar 'sister' (NomP1 syzarõ ${ }^{q}$, Est V: 1941); tütär 'daughter' (AES 202: 13); utar' 'udder' (AES 202: 10) and vassar 'hammer' (Est V: 1937). The meaning

6 Elsewhere, pakk is derived from the Proto-Germanic word form *spaka- *spako, cf. Middle Dutch spāke spaecke 'pole; dowel' (Metsmägi, Sedrik \& Soosaar 2012). 
and origin of the word hannar' (Est V: 1939, 1952) are unknown. The only adjective in this group is kõvvor r' 'curved, bent' (AES 202: 8).

-s : $\boldsymbol{\varnothing}<*_{-} \mathbf{s}: *_{-} \mathbf{h}-<*_{-}$š-. The following nouns are formed from $a$-stem words using this suffix: kikas 'rooster' (AES 202: 10; ComSg kikkaga, Mets et al. 2014: 292; cf. et kukk, see Metsmägi, Sedrik \& Soosaar 2012); rõevas : rõiva 'clothing' (Est V: 1953; cf. fi roivas 'hemp or flax bundle', Kulonen 2000: 88); säünäs 'ide (Leuciscus idus)' (AES 202: 7); varbas 'toe' (NomPl varba', Est V: 1934; cf. et varb 'rod, switch', Metsmägi, Sedrik \& Soosaar 2012) and võõras 'stranger' (Pall 1982-1989; cf. et veer 'border, edge' or blt loan). In the word saabas (Pall 1982-1989) 'boot', the suffix is added to first part of the Old Russian loanword sapogü 'boot' or the final part was lost after the suffix was added (cf. liv sōpkõz 'boot').

There are many Indo-European loans from different periods with this suffix. The Baltic loans are hammas (Pall 1982-1989) 'tooth'; ${ }^{+}$har'as 'bristle' (PrtPl harǎšsit, Est V: 1952); kinnas 'glove' (Pall 1982-1989); oon'as (Haak et al. 1994-2020) 'ram'; ratas (Pall 1982-1989) 'wheel'; saivas (Pall 1982-1989) 'pole, stake'; ${ }^{+}$taivas (Pall 1982-1989) 'sky; heaven'; udras (Pall 1982-1989) 'otter'. Of Proto-Germanic origin: haugas (Pall 1982-1989) 'hawk'; 'kangas 'cloth' (PrtSg kangast, Est V: 1939); rahvas (Pall 1982-1989) 'people'; rõngas (Pall 1982-1989) 'circle, ring'; tõbras (Pall 1982-1989) 'cattle'; varas (Pall 1982-1989) 'thief'. The suffix is lost in the Proto-Indo-Iranian loanword põrs 'piglet' (AES 202: 12; Se põrss). A word of problematic affiliation recorded in the Kraasna dialect is pormas 'floor' (Est V: 1941). The origin of the word kuvvas 'axe handle' (Est V: 1935; Vas kuvvas : kuuda) is unclear (see Junttila 2012: 287). Loans also include the as-final adjectives: hal'as 'green' (NomPl halja , Est V: 1939; AES 202: 11); ' pal'as 'naked' (Pall 1982-1989); puhas (Kallas 1903: 87) : ${ }^{+}$puhta 'clean' (SgIl puhtahõ, Est V: 1937); rikas 'rich' (Mets et al. 2014: 279).

-s : -se $\sim$-sa $\sim$-sä < *-isA. The word imis $\sim$ im's 'sow' (Est V: 1942; Kallas 1903: 32; cf. Se imä 'mother') is a denominal noun, but the word tul'is $\sim$ tul's 'collective name for ancient tools used to light a fire (e.g., flint, tinder)' (Kallas 1903: 26) is a Proto-Baltic loan, cf. lt dūlis 'a smoking piece of wood for driving away bees' (Metsmägi, Sedrik \& Soosaar 2012). The word form tulis 'fire striker' is found in Vorromaa and Setomaa (Pall 1982-1989). Adjectives formed from nouns: illos 'beautiful' (NomP1 iloza, AES 202: 8; ERA II: 87; cf. Se illos < ilo 
'beauty; joy'), makus' 'tasty?' (Haak et al. 1994-2020; cf. Se magu 'flavour, taste') and valuz 'painful' (Kallas 1903: 96; the same stem as the word valge 'white', Metsmägi, Sedrik \& Soosaar 2012) as well as from a deverbal süntsä 'polite, fitting' (Est V: 1935; cf. Se Rõu Vas süntsä $<$ sündüs $(<*$ *süntüisä) < sündümä 'to be born', Mägiste 1982-1983: 2012, Käsi 2000: 177).

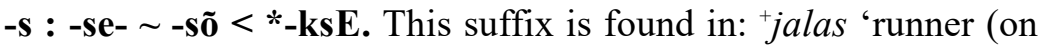
a sleigh)' (NomPl jalazõ ${ }^{q}$, Est V: 1940; in some Estonian dialects: jalakse-; <jalg 'foot'); jänes 'hare' (AES 202: 10; cf. fi jänis); ${ }^{+k e r e s ' ~: ~}$ keresist 'stones heated in a sauna and doused with water to generate steam' (Kallas 1903: R 4-12; in et dialects: kerikse-; either a Proto-

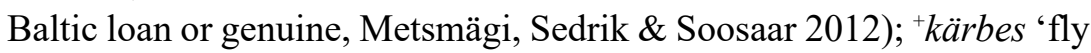
(Muscidae)' (NomPl kärpseq, Est V: 1935; Se kärbäs; it may be that -es is a form derived from the ne-suffix, cf. see fi kärpänen, Metsmägi, Sedrik \& Soosaar 2012); ${ }^{+}$oras 'young crop' (NomPl oraze, Kallas 1903: 11-3; < ora 'spike, spit', Metsmägi, Sedrik \& Soosaar 2012; in some et dialects orakse-, but cf. fi oras : oraan < *orahan); nogges 'nettle' (nõges, Kallas 1903: 45; NomPl nõgõz $\tilde{o}^{q}$, Est V: 1939; cf. Se nõgõnõ nõgõs', in et dialects nogekse-); varõs 'crow' (NomPl varõz $\tilde{o}^{q}$, AES 202: 5,25 ; cf. liv varīkš).

-ts : -tsa- -tsä- <*-tsA. This denominal as well as deverbal suffix forms are used in the names of devices and instruments: ${ }^{+}$kammits 'hobble, tangle' (kammitsõhõ, AES 202: 8; loan stem + a Finnic suffix, Metsmägi, Sedrik \& Soosaar 2012) and kol'gits kuolkts : 'a tool used for breaking flax' (ComPl kol'ksidega, Kallas 1903: 96; Mets et al. 2014: 284; Est V: 1940; cf. et kolkima 'to break flax or hemp'; e.g., Kra kolgotas kol'ksidega '(the flax) is broken with a flax-breaker'). The word 'luhits 'spoon' (ComSg luhitsaga, Kallas 1903: 87) is of Old Russian origin, cf. лъжииа 'a small spoon for giving Holy Communion'. The word kar'ts : karidzo 'piggin, a wooden bowl with a short handle' (NomPl karidzõ, Est V: 1953); cf. ru кopeu 'a small cup; a box for finely ground flour', Must 2000: 84) has been borrowed from Russian. The word labõrits 'St. Lawrence's Day' (labõritsakene, Kallas 1903: 87 ; $<$ Laurentius) is also a borrowing.

$-\mathbf{u}$, see $-\mathrm{o} \sim-\mathrm{u}$.

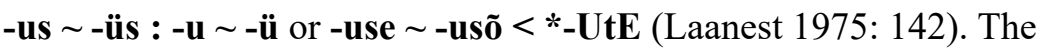
following abstract nouns are formed with this suffix: tehrüs 'health' (ComSg tehrüga, Pall 1982-1989; Est V: 1940; cf. Se terveh 'healthy'; 
about the sound change $h r<r v$ cf. Se tehrütämä 'to greet', fi tervyys : tervyyden 'health') and oigus 'rightness' (AES 202: 10; cf. Se õigus : oigusõ < oigõ 'right; honest, fair', cf. fi oikeus : oikeuden). See also the secondary suffix $-u s \sim-\ddot{u} s$.

-v : -va $\sim$-vä < *vA. The only noun derived from another noun with this suffix is allev 'urban village' (AES 202: 20; cf. et ala 'field, sphere; territory', Metsmägi, Sedrik \& Soosaar 2012). Denominal and deverbal adjectives are much more common: elläv jelläv 'alive' (AES 202: 3, 9; NomPl eläväq, Est V: 1943; cf. Se elämä 'to live'); ${ }^{+}$kirriv : kirivä 'variegated, multi-coloured' (Kallas 1903: 78; cf. et kiri : kirä 'letter; pattern'; Metsmägi, Sedrik \& Soosaar 2012); ${ }^{+}$otav 'cheap' (NomP1 odava', AES 202: 11); pallav 'hot' (AES 202: 10; cf. Se palama 'to burn'); tutva 'known' (Est V: 1935; et tuttav is a consonant stem present tense impersonal voice participle $(<*$ tunt-ta- $\beta a$, Metsmägi, Sedrik \& Soosaar 2012); verrev : verevä 'red' (AES 202: 7; ERA I: 42; veri 'blood'); ogõv 'straight' (AES 202: 8; the same stem as the et word oige 'right, correct', Metsmägi, Sedrik \& Soosaar 2012).

\section{Secondary nominal derivatives}

-dus -düs < *-tU-Us < *-tOi-Us. If the word sü̈̈düs (AES 202: 11), the meaning of which is unknown, means the absence of fault (cf. et sü̈̈taus süüdus : süüduse 'innocence', Wiedemann 1973: 1104), then it must be assumed that this abstract noun is based on a presumed adjective indicating the absence of a state or quality ${ }^{+}$süüdü. However, if it does not have a caritive meaning, then it functions as a primary suffix, which is attached to the noun referring to guilt, cf. eS süüd 'guilt'. See also $-d u \sim-d u ̈$.

-(i)st : -(i)sto $\sim$-(i)stu < *-s-ta-i (see Hakulinen 1968: 149). This suffix is known in only two words in Kraasna folk songs: 'laanist 'a low, bosky landscape?' (ElaSg laanistust, Kallas 1903: 1-10; cf. et laas : laane 'pine forest') and 'soomist 'a swampy meadow or pastureland' (ElaSg soomistost, Kallas 1903: 1-9; < soo 'swamp'; cf. soomik 'swampy area' < soovik, in which $v$ occurred in place of a hiatus, Mägiste 1982-1983: 2854, 2859; probably of the same origin: Vas soomik 'wet creature', Pall 1982-1989). 
-jas -jäs : [-ja $\sim$-jä $]<*_{-j} \mathbf{j A - s . ~ A c c o r d i n g ~ t o ~ c u r r e n t ~ d a t a , ~ t h i s ~ s u f - ~}$ fix occurs only in the nouns uohtjas : ${ }^{+}$uohtja 'thistle' (NomPl uohtja ${ }^{q}$, AES 202: 6; Kallas 1903: 45; Se oht'jas; < ohe : ohte 'awn; beard', Mägiste 1982-1983: 1816) and ruod'jas 'pole, post?' (Est V: 1938; cf. Se rood'as(s) : ruudja 'pole, post').

-k : - $\mathbf{g i}<*-\mathbf{k k - i}<*-\mathbf{k k A}-\mathbf{i}$. The following are formed with this deverbal suffix: 'juuk' : joogi 'drink' and 'sü̈̈k' : söögi 'food' (both Kallas 1903: 91).

-k : -gu $<*$-kk-o < *-kka-o or *-kk-oi < *kka-oi. This suffix has had several semantic functions. Derivatives with this suffix describe human characteristics and are formed primarily from nouns and adjectives, e.g., habõnik 'bearded man' (AES 202: 25; < habõna ${ }^{q}$ 'beard'); häbärik 'powerless; premature child? (as a curse word)' (Kallas 1903: 95; cf. fi äpärä 'bastard; degenerate'); ${ }^{+} k a a s$ ' $k \sim$ kaazik 'wedding singer' (NomPl kaazigu ${ }^{q} \sim$ kaazigó $^{q} \sim$ kaas'ku$^{q}$, AES 202: 2; Kallas 1903: 102; Est V: 1935; the same stem as kaasas 'with', Metsmägi, Sedrik \& Soosaar 2012); noor'k $\sim$ nuoorik $\sim$ nuor'k 'young wife' (AES 202: 4; Kallas 1903: 98; Mets et al. 2014: 291; cf. Se nuur' : noorõ 'young'); näidsik näitsik näädzik 'girl, young woman' (Kallas 1903: 128; cf. neitsi 'virgin; maiden' < *neine : *neitse, see Metsmägi, Sedrik \& Soosaar 2012); tütrik 'girl' (NomPl tütrigu $u^{q}$, AES 202: 6; Est V: 1937; cf. Se tütär'). See also $-k: g a<*_{-} k k a$ (Sec. 3).

The same suffix is used to derive the names of objects: linik 'kerchief, tablecloth' (Kallas 1903: 29; cf. lina); 'länik 'a wooden container for milk, etc.' (NomPl länigu $u^{q}$, Est V: 1935; Proto-Baltic stem, cf. It lenta 'table; plank', Metsmägi, Sedrik \& Soosaar 2012); nüs'k 'milk pail' (Haak et al. 1994-2020; cf. eS nüss 'milking'; according to Neetar 1990: 27, nüssik is deverbal); pilak 'splinter holder (a clip for holding burning kindling)' (Est V: 1952; cf. pilu? 'slit', Metsmägi, Sedrik \& Soosaar 2012). Associated with the daily cycle: ${ }^{+}$hommok $\sim$ hommuk $\sim$ hummuk 'morning' (AblSg hommogult hommugult hummugult, AES 202: 21; Mets et al. 2014: 282, 283; the same stem as et homme 'tomorrow', Metsmägi, Sedrik \& Soosaar 2012) and ódag : oddaguld 'evening' (Mets et al. 2014: 289, 290). In adjectives, $-k$ appears to function as a diminutive suffix: poolik 'half' (Kallas 1903: 1-27; cf. Se puul' : poolõ 'half') and 'väiku 'small' (AllSg väikule, Kallas 1903: 14-12; *vähi-kko <*vähä 'little; few', see also Metsmägi, Sedrik \& Soosaar 2012) 'small' also in the noun 'sagarik: sagariku 'rain shower' (Kallas 1903: 80). It is 
not clear whether the words with unknown meanings - iešk (AES 202: 7, cf. Se etc. eesik 'a cow's name') and tõešk (AES 202: 7) - come from the ordinal numerals 'first' and 'second'.

The word vanig' $\sim$ van'k 'wreath' (Est V: 1938; Kallas 1903: 29) and perhaps also tatrik: tatrigu 'buckwheat' (AES 202: 7, 25; cf. ru татарка, Metsmägi, Sedrik \& Soosaar 2012; with the diminutive suffix *-ikkoi, Mägiste 1982-1983: 3096) cannot be considered loans. The nouns puuzlik 'idol' (Kallas 1903: 67; the origin of this word is uncertain, Metsmägi, Sedrik \& Soosaar 2012) and ${ }^{+} u n i k \sim u n^{\prime} k: u n^{\prime} k o h o$ $\sim$ hun'kohõ 'heap, pile' (Mets et al. 2014: 285) are difficult to semantically categorise.

It is completely uncertain for the words keranik (Est V: 1935) and pelenik (Est V: 1949), because their meaning is unknown. In cases when documentation is unclear, cf. e.g., Se kelenik 'servant of an abbot' $(<\mathrm{ru}$ келейник, Must 2000: 94, but also Kod kärinik 'noisemaker' and kerinik $\sim$ körinik 'sickly' (Haak et al. 1994-2020), then these may contain -nik of Russian (or Latvian) origin instead.

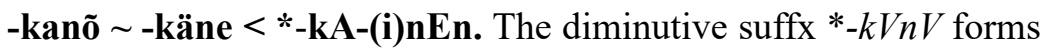
many new words. Most of these are recorded by Kallas. An abundance of diminutives is very characteristic of Võro, which may be the result of Russian and/or Latvian influence. In front-vowel words, the compound suffix has the form -kene, but in back-vowel words it is either -kanõ or -kõno. ${ }^{7}$ Though the latter come from the same Finnic suffix, it is sensible to keep these separate in Estonian. The following diminutive nouns are formed using the kanõ-suffix, which denotes either the smallness of creatures or personalities or an affectionate attitude towards them: gul'ukkanõ 'pigeon' (AES 202: 25; < gul'u 'pigeon (dim.)'); haan'akkanõ 'hay (dim.)' (AES 202: 4; < hain 'hay'); hatakane (Kallas 1903: 125; < hatt 'female dog; whore'); hõngõkkane (AES 202: 13; < hõng 'breath; soul'); jumalakkane (AES 202: 4; < jummal' 'god'); kaazõkkanõ (Est V: 1953; < kaas' 'lid, cover'); 'kablakanõ (NomPl kablakaze $^{q}$, Est V: 1940; < kabõl' 'string, cord'); ${ }^{+}$kalakanõ : kalakazõ (Mets et al. 2014: 291; < kala 'fish'); ${ }^{+k a m a k a n o ̃ ~(P r t S g ~ k a m a k a i s t e, ~}$ 3-20; < kama 'a finely milled flour mixture used for making porridge, baking, etc.'); kanakane (Mets et al. 2014: 207-17) < kana 'hen';

7 The base words of the $K V n V$-diminutives were derived by the author of this article with particular reference to Seto words (Käsi 2011). 
kan'kanõ (Est V: 1951; kann' : kanni 'jug'; in this and other examples typically there is syncope resulting in the palatalisation of the preceding consonant); kar'pkanõ (Est V: 1952; < karp : karbi 'box, case'); kaškanõ (Est V: 1953; < kašk 'overcoat'; Se kask: kaska kasuk: kasuga); +kedzokanõ (PrtSg kedzokaist, Kallas 1903: 12-4; cf. Se ketso 'spindle' $<*$ *keta-s- 'disc' + *-oi, see Mägiste 1982-1983: 790); kikkakanõ (Kallas 1903: 3-14...15; < kikas 'rooster'); *kogrõkanõ (kogrokane, Br: 2-2; $<*$ kogõr') 'crucian carp', kor'v'kanõ kuor'v'kanõ (AES 202: 8; Est V: 1953; < korv' 'basket'); ${ }^{+}$kostikanõ : kostikaze (Kallas 1903: 3-23; < kost' 'guest', Must 2000: 129); kuh'akane (Kallas 1903: 14-8; < kuhi 'rick, stack'; kuningakane (Kallas 1903: 80; < kuningas 'king'); ladvakkanõ (AES 202: 7; < ladõv 'top (of trees, etc.)'); *ladzõkan *ladzõkõn ${ }^{+}$ladzõkanõ (latzakan, Br: 4-1; ladzekane, ERA I: 67; < lats' : ladzõ 'child'); 'langakanõ (PrtSg langakaist, Kallas 1903: 12-5; < lang 'yarn'); l'el'l'okanõ (Mets et al. 2014: 207-3; multiple diminutive, using palatalisation, $o$ - and kanõ-suffixes; cf. Se lelo $\sim$ leloo $\sim$ lelooh 'leelo (a type of Estonian folk song)'); ${ }^{+}$livvakanõ (ElaSg livvakazest, Kallas 1903: 88; < liud : livva 'a type of large serving dish'); magilkakanõ (Mets et al. 2014: 281; < magilka 'grave' < ru могилка 'grave (dim.)'); munakane (Kallas 1903: 3-12; < muna 'egg'); ${ }^{+}$naaz'ôkanõ : *naaz'ôkazõ (naesõkaze, Kallas 1903: 19-2; < naan'õ 'woman, wife'); oinakkanõ (Est V: 1953; < oinas 'ram'); ${ }^{+}$ollõkanõ (PrtSg ollekaiste,

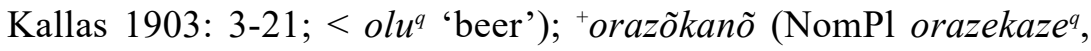
Kallas 1903: 103; < oras 'young crop'); paabakane (Kallas 1903: 124); $<$ paaba 'old woman' < ru бабa; Se paaba); pad'akanõ (Mets et al. 2014: 280; < padi 'pillow'); painakane 'nightmare, incubus' (Kallas 1903: 96; cf. eN painakas 'nightmare', Neetar 1990: 57); pikrikanõ (Est V: 1941; < pikri 'cup, shot glass'); pos'kane puos'kanõ (Est V: 1945; Kallas 1903: 124; < poiss' 'boy, young man'); puhmakkanõ (AES 202: 6; < puhm 'bush'); puuzlikanõ (AES 202: 12; < puuslik 'idol'); +pungakanõ (IllSg pungakaizdõ, Kallas 1903: 22-5; recorded in Kallas's notebook instead as: PrtSg punga (ERA I 87); < pung 'wallet'); ${ }^{+}$sainakanõ (PrtSg sainakaist, Kallas 1903: 12-6; sain 'wall (here: unit of measure for fabric)'); saunakkanõ (AES 202: 7; < saun 'sauna'); teedakane (Kallas 1903: 124; < teeda 'old man' < ru ded 'grandfather'; Se teeda); tsirgukane (vihmatsirgukane, Kallas 1903: 32; < tsirk 'bird'); tsurakkanõ (AES 202: 5; < tsura 'boy; young unmarried man; helper'; Se tsura); tütrikanõ (AES 202: 10; < tütrik 'girl; young unmarried 
woman; female farm worker', see Sec. 3); vaderikane (Mets et al. 2014: 291; < vadõr' vatõr' 'godparent'); varzakkanõ (AES 202: 3; < vars 'foal'); vazigakkanõ (AES 202: 3; < vazik 'calf'); viglakane (Kallas 1903: 14-7; < vigõl' 'pitchfork'); vihmakane (Kallas 1903: 9-1; < vihm 'rain'); vikakaarikane (Kallas 1903: 9-3, 4; < vikakaar' 'rainbow'; Se vikat'kaar') and 'voonakanõ (NomP1 voonakazõ ${ }^{q}$, AES 202: $3 ;<$ vuun 'lamb'). Words with unknown meanings include: ažkanõ (Est V: 1951), ed'kanõ (Est V: 1953) and Jintskane (Kallas 1903: 124). The unique form vaderidzekaze (Kallas 1903: 21-3; < vatõr' 'godparent') has the plural meaning 'godparents (dim.) together', see -dze- $\sim-d z \tilde{o}-$.

There are relatively few adjectives with this suffix. Some of these are formed from nouns and denote the content of a material: ${ }^{+}$aganakano 'of chaff, containing chaff' (NomPl aganakas', Mets et al. 2014: 285; $<$ akan': agana 'chaff'); juonõkanõ 'striped' (AES 202: 13; Se joonikanõ < juun' 'stripe') and kõevanõ 'of birch; made of birch-wood' (Est V: 1944; < kõiv 'birch'). The other adjectives with this suffix are derived from adjectives, e.g., jämkäne 'fat; coarse (et jämedune)' (Kallas 1903: 125; cf. Se jämükene < jämmeh 'fat; coarse'); ohkanõ 'thin (et ôhukene)'

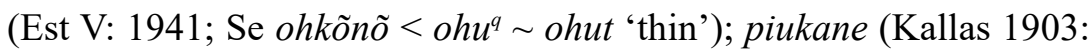
125; piukõnõ 'in length' (Kallas 1903: 125; cf. Se piu 'in length', piutus 'length; height'), and sõgõhõkkane 'blind (et pimedakene)' (AES 202: 26; < sõkõ 'blind'). In this case, the diminutive meaning is only partially evident. The diminutive is an adjective of noun origin: ${ }^{+} p i z u$ kanõ : pizukaze 'small (et pisikene)' (Kallas 1903: 1-24; < *pisu 'drop; a small amount', Metsmägi, Sedrik \& Soosaar $2012[<*$ pisa]).

The following are secondarily nominalised: armakane 'beloved' (Kallas 1903: 19-1; < armas : arma, Käsi 2011: 39); mustakane 'evil spirit, devil; lit. little black one (et mustakene)' (Kallas 1903: 95; < must 'black'); vanakkanõ 'dear old person (et vanakene)' (Est V: 1945; < vahn 'old', Pall 1982-1989) and *väikokan[õ] *väikokõn[õ] 'little one (about children) (et väiksekene)' (waiekan, Br: 4-2; väiko väiku 'little'). Of adverbial origin: suutskakkanõ (Est V: 1942; cf. Se ts'uut 'a little bit, a small amount' < ru чymb) and tsipakõnõ (Pall 1982-1989; $<$ tsipa 'a little bit, a small amount', Metsmägi, Sedrik \& Soosaar 2012, Käsi 2011).

-kene $\sim$-kõñ $<*$-k(k)E-(i)nen $<*$-k(k)A-(i)nen. Nouns are derived most of all with this suffix: aiakene (Kallas 1903: 73; < aid 'garden'); anumakene (Kallas 1903: 82; < annom 'vessel; container'); 
ezändäkene (Kallas 1903: 80; < ezänd 'lord'); hainakene (Kallas 1903: 45; < hain 'hay'); hiireherrnekene (Kallas 1903: 44; < hiireherneh 'vetch'); 'huunõkõnõ (hoonekest, Kallas 1903: 87; < hoonõh 'building'); humalakõnõ (ERA III: 196; < hummal' 'hops'; hõimukene (Kallas 1903: 92; < hõim 'tribe, people'); här'äkene (AES 202: 3; < härg' 'bull'); *imekene (Br: 3-1); < imä 'mother'); juudakene (suujuudakene, Kallas 1903: 125; < Juudas?); ${ }^{+k a a z o ̃ k o ̃ n o ̃ ~(k a a z o ̃ k k o ̃ z o ̃ g a, ~ A E S ~ 202: ~ 7 ; ~<~ k a a s ' ~}$ 'lid, cover'); kah'akene (Kallas 1903: 87; < kahi 'a drink offering'); kanakõnõ (Kallas 1903: 3-15; < kana 'hen'); karmukõnõ (AES 202:

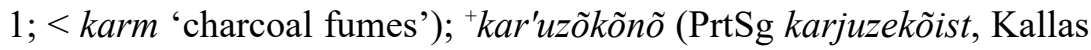
1903: 7-11; < kar'us 'herder'); ker'kene (Kallas 1903: 124; < ker'go; cf. Se ker'go 'a small bench'); kivikene (Kallas 1903: 9-5; < kivi 'stone'); kupakõnõ (Kallas 1903: 82; < kupp 'a small cupping glass'); NomPl *käledzekeze $e^{q} \sim$ käledekez' (ERA II: 85; Kallas 1903: 21-2; < käledze ${ }^{q}$ 'brothers' wives'. A singular form has not been observed, cf. older kélline (Göseken 1660, cited by: Vääri 2013: 156; Se kälü 'husband's

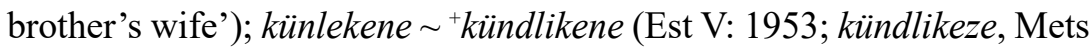
et al. 2014: 281; < künnel' 'candle'); labõritsakene (Kallas 1903: 87;

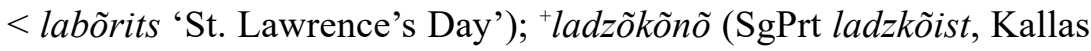
1903: 7-10; < lats' 'child'); 'laulukõnõ (NomP1 maalaulukeze, Kallas 1903: 103; < laul 'song'); lehmäkene (Kallas 1903: 10-5; < lehm 'cow'); 'leiväkene (AllSg leivakezele, Kallas 1903: 93; < leib 'bread'); lelokene (Kallas 1903: 1-1; < lelo 'leelo (a type of Estonian folk song)'); maamakene (Kallas 1903: 1-15; < maama 'mother' < ru мaмa; Se maama); mer'kene (Kallas 1903: 124; < meri 'sea'); munakõnõ (NomPl munakeze, (Kallas 1903: 128; Mets et al. 2014: 207-13; < muna 'egg'); Märtkene (Kallas 1903: 124; < Märt 'a man's name'); origugene (Kallas 1903: 84; < orik 'boar'); paabakene (Kallas 1903: 128; < paaba 'old woman'< ru баба); ${ }^{+}$palakõnõ (ComSg palakezega, Kallas 1903: 22-2; $<$ pala 'piece'); ' piiragukõnõ (NomPl piiragukõzõ ${ }^{q}$, Kallas 1903: 21; $<$ piirak'(large) pie (a type of food)' < ru nupoz); pinikene (Kallas 1903: 125; < pini 'dog'); puhmakõnõ (kadajapuhmakõnõ, Kallas 1903: 73; $<$ puhm 'bush'); ${ }^{+}$rihekene (r'ihekeist, Kallas 1903: 87; < riih 'threshing barn'); rästäkene (Kallas 1903: 32; < rästäs 'thrush'); rät'kene (Mets et al. 2014: 281; < rätt' 'kerchief; towel'); ${ }^{+}$rüpkene (IllSg rüppkõizdõ, Kallas 1903: 101; < rüpp 'lap'; Se rüpp : rüpü); saanikõnõ (Kallas 1903: 3-4; < saan' 'sleigh'); sannakõnõ (Mets et al. 2014: 290; < sann 'sauna'); ${ }^{+}$soolakõnõ (AllSg soolakezele, Kallas 1903: 93; < suul : soola 
'salt'); surakõnõ (Mets et al. 2014: 207-14; < sura 'egg yolk', cf. et sora); ' sõnakõnõ (NomPl sõnakeze ${ }^{q}$, Kallas 1903: 22-3; < sõna 'word'); *suukõnõ (sů ’’kene, Kallas 1903: 92; < sugu : suu 'gender; family; generation'); sõirakõnõ (ERA I: 63; < sõir 'cheese'; sõzarakõnõ (ERA IV; < sõzar 'sister'); tedrekene (Kallas 1903: 5-1; < tedõr' 'grouse'); t's'urakõnõ (Est V: 1934; < ts'ura 'boy; young man'); ${ }^{+}$tehrükene (PrtSg tehr'ükeist, Kallas 1903: 100; < tehrüs 'health' < *tervehüs; Mägiste 1982-1983: 3139); tingäkene (Est V: 1937; < ting 'money' (cf. Seto ting : tingä 'money' < ru деньги'); 'tõprakõnõ (NomP1 tõprakezeq, Kallas 1903: 78; < tõbras 'cattle'); udarakene (Kallas 1903: 125; < utar' 'udder'); ut'kene (ERA III: 223; < utt' 'ewe'); vaibakene (ERA II: 106; $<$ vaip 'carpet, rug'); vahnembakene (Kallas 1903: 11-11; cf. et vanõmb 'parent'; nominalised form of the comparative form of the adjective); varzakõnõ (Kallas 1903: 32; < vars 'foal'); velekene (ERA II: 100; $<$ veli 'brother'); 'villakõnõ (NomPl villakes ${ }^{q}$, Mets et al. 2014: 284; < vill 'wool'); voonakene : voonakeze (Kallas 1903: 32, 127; < vuun 'lamb'); võizmakõnõ (ERA I: 63; < võizi 'butter'). The only completely unique noun formed from an adjective is pikene $\sim$ pikkene $\sim$ pikäne

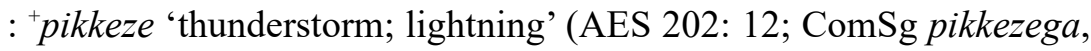
ERA III: 182; Kallas 1903: 90; Se pikne pikse; < pikk 'long, tall', Mägiste 1982-1983: 2042).

Only a few adjectives are known, which are formed with the diminutive suffix -kene $\sim$-kõnõ, e.g., *jelläkene (jellekene, $\mathrm{Br}: 3-1 ;<$ jell? 'gentle'); noorekene (ERA II: 100; nuur' 'young'; ${ }^{+}$pehmekene (NomPl pehmekez", Est V: 1948; < pehmeh 'soft'); *raaskõnõ 'a little bit, a small amount' (Pall 1982-1989; cf. Se raas : raasa raasu 'a little bit, a small amount') and veikene (Est V: 1938; < veiko veiku 'small', see Sec. 3). Of these, only raaskonno is derived from a noun, the others come from adjectives.

-lanõ $\sim$-läne < *-lA-inEn. This compound suffix occurs mainly in nation and animal names and attaches to vowel as well as consonant stems. The documented nation names - some, true enough, with distorted meanings - are the following: musstlane 'some kind of evil spirit' (Kallas 1903: 95; cf. et mustlane 'Romany' < must 'black'); suumlanõ 'Finnish' (AES 202: 1; cf. et Soome); vadilanõ vadylynõ 'a curse word' (AES 202: 8; Est V: 1951; Se vadilanõ; cf. et vadjalane 'Votian', Kallas 1903: 95) and vindläne $\sim^{+}$vineläne $\sim \sim^{+}$vinlanõ $\sim$ vinndlanó 'Russian' 
(NomPl vindläze $e^{q} \sim$ vineläže $^{q} \sim$ vinlaze $^{q} \sim$ vinndlaze $e^{q}$, AES 202: 4, 10; Est V: 1937, 1945; Kallas 1903: 39, 40; Se veneläne vindläne; cf. Vene).

Insect and bird names include: ${ }^{+}$hüurläne 'wasp' (NomPl hüürläze, Kallas 1903: 47; Se hüürläne); kihulanõ 'mosquito' (Haak et al. 19942020; NomPl kihulas ${ }^{q}$, Est V: 1945; cf. et kihu 'black fly', Metsmägi,

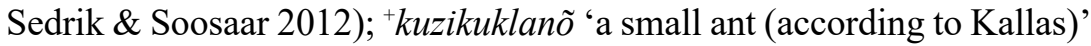
(NomPl kuzikuklazõ ${ }^{q}$, Kallas 1903: 22; Se kusikuklane 'ant'); kärbläne 'fly' (Est V: 1935); pääzläne 'swallow' (NomP1 pääzlädzeq , AES 202: 5, 10); 'tialanõ 'titmouse' (tialazehain 'a type of plant', Kallas 1903 45; Se tialanõ; cf. et tiha: tiha 'titmouse', Wiedemann 1973: 1153); varblanõ 'sparrow' (NomPl varblaz ${ }^{q}$, Est V: 1938, 1946). The suffix in question also appears in two other nouns: kozilano 'suitor' (ComSg kosilazõga, AES 202: 26; Mets et al. 2014: 279; cf. et kosjad) and vaimlanõ 'enemy?' (AES 202: 8; cf. Se vaimlanõ vainlanõ 'enemy' and et tuhinvaimlane 'religious fanatic', Wiedemann 1973: 1291). Based on Seto and other South Estonian materials, a more believable base word would be vain 'hatred'.

-las < *-la-s. Only kaklas 'owl' (AES 202: 25; cf. Se kakk 'owl') is derived with this suffix. In this case, an incorrect recording of the word cannot be ruled out; however, this suffix is also used in Estonian and Finnish (see Hakulinen 1968: 134, 171).

-lik < *-lä-kkä-oi. Only pä̈̈lik ‘sun' (Kallas 1903: 88; cf. Vas päivlik 'sun'< päiv 'day; sun'; see also Neetar 1990: 80) is known to be derived using this denominal suffix in Kraasna.

-line $\sim$-lino $<*$-IlA-inEn. The suffix appears in the following nouns derived from adjectives: pääline 'cream' (Mets et al. 2014: 287; cf. Se päälisepiim päälüsepiim 'cream', pääline 'upper' < pääl 'above; on top of'; it is also possible that it was derived using the suffix -us $\sim-\ddot{u} s$, cf. päälisse päälüsse 'haulms') and virmalinõ 'a curse word' (Kallas 1903: 95; cf. et virmalised 'polar light', fi virmalliset 'celestial signs' and fi virma 'fast, lively', Metsmägi, Sedrik \& Soosaar 2012). The suffix also derives adjectives from nouns: aolinõ 'of a time' (NomPl üteaolidze 'simultaneous', Est V: 1950, also Haak et al. 1994-2020; cf. Se aig 'time'); ${ }^{+}$äline : 'relating to age' (NomPl üteiälidze ${ }^{q}$ 'of the same age', Est V: 1950; cf. Se igä 'lifetime; age'); ikuline ‘weepy' (Kallas

8 The compound word tuhinvaimlane dates to the 19th century and its base word is vaim 'spirit' (Mägiste 1982-1983: 3653). 
1903: 13-6; cf. Se $i k k$ 'weeping'); ${ }^{+} k a r v a l i n o \tilde{~ ' i n ~ s o m e ~ c o l o u r ' ~(K a l l a s ~}$ 1903: 1-12; Se karv 'colour'); vallalinõ 'unmarried' (AES 202: 3; cf. Se vald 'field, sphere'); varbuline 'made of poles' (Kallas 1903: 73; cf. Se varb : varva 'pole'). The adjective kurvaline (Kallas 1903: 13-7; also $\mathrm{Se})$ 'sad' is derived from an adjective, cf. et kurb.

-mes : -mõs <*-mE-s. The following are derived using this suffix: ${ }^{+}$sõorrmõs 'chute, groove; nostril' (NomPl s'yyrmõ $\tilde{o}^{q}$, AES 202: 13; cf. et sõore, Se Vas sõ̃rmõs, liv sõõrmõz, but fi sierain : sieraimen 'nostril'; cf. et sõ̃or 'circle', Metsmägi, Sedrik \& Soosaar 2012).

-mine : -miže $<*$-mA-inEn. Suffixes denoting actions or their objects form action nouns: elämine 'living' (Est V: 1940; cf. Se elämä 'to live; to habit'); kozimine 'courtship' (ERA II: 168; cf. Se kosima 'to propose (marriage)'); 'šüümine : šü̈miže 'eating' (AES 202: 12; Se sü̈mmä 'to eat').

-ndus $<*$ nt-us. This suffix is found only in nouns derived from other nouns: ${ }^{+}$soend 'werewolf' (PrtSg soendust, Kallas 1903: 96; cf. Se soend $\sim$ soendik $\sim$ soendus < susi 'wolf'). Unlike many deverbal suffixes in Estonian dialects (see Neetar 1990: 117 and others; Mund 2005), the denominal does not change the meaning of the word.

-ng : -ngu / -n-gü < *-n-ko-i < *-n-ka. Most $n g$-suffixed words appear in eastern sub-dialects of South Estonian (Tanning 1955: 128, $129,132,133)$. Based on verbal nouns: Kra ${ }^{+}$massang 'tax; payment' (PrtSg masangut, Est V: 1943; Mets et al. 2014: 284; cf. Se masma 'to pay') and 'upung : upungu 'flood' (Kallas 1903: 87; cf. Se upung $<$ uppuma 'to drown'; Neetar 1990: 125). The deverbal suffix is found in the words 'nüssäng : nüssängü 'milking time' (TermSg nüssänguni, Kallas 1903: 4-6; cf. Se nüssäng 'milking' and nüsmä 'to milk') and +palang : palangu 'burning, fire' (Kallas 1903: 87; cf. Se palang 'rush, hurry' < palama 'to burn'). In the word nüssäng, the noun originally describing the action developed to describe the time of that action, e.g., see also Hargla ahu palang 'stove kindling; stove kindling time, i.e., evening' (Neetar 1990: 126).

$\mathbf{- 0} \sim-\mathbf{u}<*_{-o \mathbf{i}} \sim *_{-\mathbf{o} \mathbf{i}}$. For variation in the Kraasna suffix see $-o$ $\sim-u$ (Sec. 3). Originally, small size or affection were expressed with a diminutive suffix. Derived forms include: ${ }^{+}$haro 'branch' (ComSg haroga, Est V: 1940; cf. Se haro, et ara < *hara 'branch'); jahu 'flour' (Est V: 1940; cf. Se jahu jauh 'flour' and jauhma 'to mill, to grind; fi jauho(t)'); kodo 'home' (Mets et al. 2014: 292; cf. Se koda: kua 
'test; shell; crust'; Mägiste 1928: 8); ono jimä veli 'uncle (mother's brother)' (Kallas 1903: 101; cf. fi eno; the same stem as in the word enam 'more', Metsmägi, Sedrik \& Soosaar 2012; Mägiste 1928: 5); the nickname T'eto (Est V: 1936); tsirk: ${ }^{+}$tsirgu 'bird' (Mets et al. 2014: 203). It is possible that moro 'bitter' (AES 202: 13; the same stem as et mõrk 'bitter, bitterish', Metsmägi, Sedrik \& Soosaar 2012; Finnic *moroi or *moru, Mägiste 1982-1983: 1602) is a diminutive adjective. In the first case, two diminutive suffixes expressing small size or reduction in size were attached to the stem.

A portion of Kraasna diminutive nouns have become $u$-final, e.g., aigu 'time (dim.) (et ajake)' in the verse Urbepäivä, armas aigu 'Palm Sunday, dear time' (Kallas 1903: 17-1; cf. Se aig 'time'); nickname Pet'u (AES 202: 11) and apparently also tõrdu 'vat' (Kallas 1903: 89; Se tõrdo tõrdu; cf. fi torto 'kneading trough; barrel'; Mägiste 1928: 17) as well as perhaps ${ }^{+}$parm 'gadfly' (NomPl parmu', AES 202: 5; cf. descriptive fi paarma, Kulonen 1995: 281; it is not impossible that the shift to $u$-final inflection occurred following apocope).

In the case of the words moro 'grass; lawn' (Est V: 1937), ${ }^{+}$porrgo : põrgohe 'hell' (Est V: 1953) and taro 'hive' (Kallas 1903: 25), it is unclear whether this is genuine or borrowed material. For example, in the case of moro, fi moro 'chickweed (Stellaria media)' and ProtoGermanic mūrōn(-) are given for comparison (Metsmägi, Sedrik \& Soosaar 2012: 289).

-rm : -rma $\sim$-r-mä $<*-\mathbf{r}-\mathbf{m A}$. The following is derived with this suffix: 'häijerm : 'häijermä 'flower' (NomPl häijermäa , AES 202: 4; Se häierm : häiermä häiermu; the basis for derivation is etymologically the same as et õis : oie 'flower', Mägiste 1982-1983: 4020, cf. also the suffixed form Se häidse $q$ 'flower').

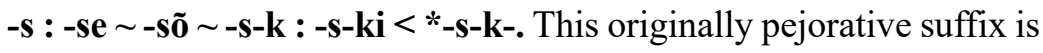
very characteristic of South Estonian dialects. In some sense conditionally, the following can be placed here: kodass' 'eagle; hawk' (AES 202: 3; eS metathesis has occurred in this word, cf. et kotkas, Mägiste 19821983: 969); puraśk 'large chisel' (Est V: 1941; eS puras purask, Pall 1982-1989 < pura 'icicle; an object of this shape', Metsmägi, Sedrik \& Soosaar 2012) and sizas 'nightingale' (Kallas 1903: 32; Metsmägi, Sedrik \& Soosaar 2012; eS sisas sisask, Pall 1982-1989; cf. et sisa 'nightingale'). From a synchronic perspective, $-s$ is a simple suffix (see Sec. 3), from a diachronic perspective, however, it is secondary. 
-sine < *-s-(i)nEn. The adverb ammuužine 'ancient' (AES 202: 11; cf. Vas Se ammunõ < ammu 'long ago'; Har ammusine; see also Käsi 2000: 174) is derived with this suffix. ${ }^{9}$

-st : -sto -stu, see -(i)st : -(i)sto $\sim$-(i)stu.

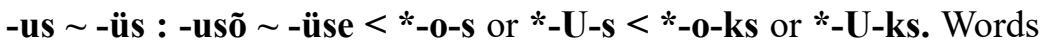
derived with this suffix describe actions and their results. The following nouns are formed from nominals: kar's 'herder' (Est V: 1942; Mägiste 1982-1983: 708, cf. et kari 'herd'); *kipõkü̈̈dzüs? 'evil spirit, devil' (kipeküüzüs, Kallas 1903: 78; cf. Se kipõ 'bitter; stiff; lively' ${ }^{+}$küüds 'nail'); lõhmus : lõhmuze 'linden' (Est V: 1941, 1946; cf. fi lehmus 'fat and weak; linden', Kulonen 1995: 58); põigus 'crossbeam; transverse bandage' (Pall 1982-1989; cf. Seto: põigus põikus 'a crossbar connecting pairs of sledge spokes' (Saar et al. 2020), Rõu põik; see also Mägiste 1982-1983: 2273); sõrms : *sõrmuzõ 'ring' (AES 202: 4; sõrmuиzõ, Mets et al. 2014: 279; < sõrm 'finger'); ${ }^{+}$sälüs 'breeching (a part of a horse harness)' (Pall 1982-1989; cf. Se säl'g : sälä 'back (part of the body)'); ülegohs ülegos ülegus 'evil spirit, devil', lit. 'a wrong', cf. et ülekohus 'injustice' (AES 202: 28; Kallas 1903: 95; not believable that the eS word < koht 'place', see Metsmägi, Sedrik \& Soosaar 2012), because the Se word is kotus 'place' $(<* k o t t)$; maybe a eN loan?). NomPl taoze ' '(horse's) collar' (Est V: 1934) is related to the noun et tagus, which comes, in turn, from the adverb taga 'behind'

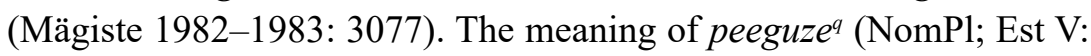
1940) remains unclear.

Nouns derived from verbs include: ${ }^{+}$katus : katsõt 'roof' (Mets et al. 2014: 288; cf. katma 'to cover'); ${ }^{+}$kohetus $\sim$ kohtus : kohetuze 'dough left to rise' (Kallas 1903: 128; PrtSg koh'tust, Mets et al. 2014: 286; cf. Se kohe-ta-ma 'to raise, to rise' < eS kohuma 'to expand; to rise', Haak et al. 1994-2020); kumarus 'bowing' (Mets et al. 2014: 291); kõlks : ${ }^{+} k \tilde{o} l g u z \tilde{o}$ 'chaff store-room (et aganik); a hay barn (near home)' (NomPl kõlguzõ ${ }^{q}$, Est V: 1937, 1947; cf. Se kõlgus : kõlgusõ $\sim$ kõlksõ); mõistuz : *mõistuzõ 'mind; riddle' (mõistuzekõne, sõnamõistus 'riddle', Kallas 1903: 103; Se mõistus 'consciousness; mind; riddle', cf. mõistma

9 Further research is needed on the relationship of -sine, -skine, and -tsin -tšin, cf. Urv ammuskinõ, Lei Lut ammutsin; Har ennesine enniskine 'recent', Rõu Urv inneskine 'recent; previous; former', Se inniskäne 'recent', Lei jennemuistutšin 'ancient' (Haak et al. 1994-2020). 
'to understand'); ${ }^{+}$uhtus 'flatulence' (AdePl puhtusil, Mets et al. 2014: 291); ${ }^{+}$pü̈̈rüs : pü̈rrüze 'twirling stick' (Mets et al. 2014: 286; Se pü̈̈rüs 'twirling stick; whorl of oat plants'); 'tapõlus 'fight, battle' (tapeluze, Kallas 1903: 52); 'virus 'arch above the oven (et vomm, ahjukumm)' (AdePl virusil, Kallas 1903: 124; cf. viruma 'to lie (down)', Mägiste 1982-1983: 3885). These nouns can refer to a person (e.g., kar's), trees (lôhmus), objects (sõrms), and abstract concepts like tehrüs, ülegohs.

Some of the relevant words end in the sound sequence hus $\sim$ hüs, of which $h$ is a semelfactive suffix $\left(*_{-} h t-: *_{-} h \delta->*_{-} h t-: *_{-} h-\right)$ and belongs to the base word: 'lebähüs 'lying down after a meal' (PrtSg lebähüst, Kallas 1903: 100; *lebähtämä); ${ }^{+}$mälehüs 'memories' (PrtSg mälehüst Kallas 1903: 104; cf. Se mälehtüs 'memories; food that is chewed', mälehtämä 'to remember; to memorialise'); tulõhus 'occurrence; occasion' (AES 202: 11); 'unõhus 'forgetting' (InsPl unehuizi, Kallas 1903: 18-2; cf. Se and others unõhumma 'to forget about'); vanhus 'age' (Est V: 1945; cf. Se vanhus, Vas vanahhuss).

\section{Summary}

Despite the limited amount of documented vocabulary, fortunately it was possible to find many nominal derivatives in the Kraasna dialect using 18 derivational suffixes formed from 20 primary suffixes and 21 derivational suffixes formed from 21 secondary suffixes. Kraasna suffixes mostly resemble those of Seto. Only the compound suffixes (-i) $s$-to, -la-s, and -ži-ne, which derive just a few words (kaklas, laanist, soomist, amтииžine) are not characteristic of Seto. The latter suffix also is found in the Hargla, Leivu, and Lutsi dialects. The suffix -eh was characteristic of the Kraasna dialect, which is the assimilated form of *-ek and * $e \check{s}$, while in Seto South Estonian these may occur in parallel as $-e h$ and $-e^{q}$. In oblique cases, the derivational suffix -eh still occurs in a mid-19th century folk song in one word PrtSg *valgõ-hö-ta 'white', but by the beginning of the 20th century it had been lost, cf. *valgõt. The diminutive suffix -kanõ, was widely used in the Kraasna dialect.

Most Kraasna nominal derivatives have correspondences in Seto, only a few have not been observed: kipõküüdzüs 'evil spirit', tukõm 'support', and vadoridz $\tilde{O}^{q}$ 'godparents'. The words laudadz $\tilde{O}^{q} \sim$ laadadz $\tilde{O}^{q}$ 'an offering made to the cowhouse gods' and puzanõ 'bitter' 
only appear in the Kraasna dialect. The Kraasna dialect, which separated from Seto 300 years prior to its documentation at the beginning of the 20th century, is surprisingly similar to the latter. It would be interesting to know to what extent later connections with Setomaa harmonised both dialects. For example, one local manor lord who also owned manors in Setomaa, brought young Seto women from Golina manor located ten versts from Petseri - as wives for young Kraasna men. The same manor lord brought people from Kraasna to work on his Setomaa manors, likewise Setos came to Kraasna bringing fish to sell (Kallas 1903: 8-9, 36, 46).

\section{Abbreviations}

Abl - ablative, Ade - adessive, All - allative, blt - Baltic, $\mathrm{Br}$ - a folk song sent by Brandt (see Ernits 2018), dim - diminutive, eS - South Estonian, Ela - elative, eN - North Estonian, et - Estonian, fi - Finnish, Gen - genitive, germL - Low German, Har - Hargla, Ill - illative, Ine inessive, Ins - instrumental, Lei - Leivu, liv - Livonian, lt - Lithuanian, Lut - Lutsi, Nom - nominative, ruO - Old Russian, Prt - partitive, $\mathrm{Pl}$ - plural, Rõu - Rõuge, ru - Russian, Se - Seto, Sg - singular, Term terminative, Tra - translative, Urv - Urvaste, Vas - Vastseliina

\section{Archival sources}

AES 202 = Akadeemilise Emakeele Seltsi ülevaated; Häälikuloolisi andmeid ja tekste

Kraasna murdest (Academic Mother Tongue Society overviews; Sound historical data and texts in the Kraasna dialect); Heikki Ojansuu; 1938; http://emsuka.eki.ee/ view-book-collection/2519 (Tallinn, Eesti Keele Instituut (Institute of the Estonian Language) / Emakeele Selts (Mother Tongue Society))

ERA I = ERA Kallas M4: I (Tartu, Eesti Kirjandusmuuseum (Estonian Literary Museum), Eesti Rahvaluule Arhiiv (Estonian Folklore Archives)).

ERA II = ERA Kallas M4: II (see previous).

ERA III = ERA Kallas M4: III (see previous).

ERA IV = ERA Voolaine M1 (see previous).

Est V = Estonica V (Helsinki, Suomalaisen Kirjallisuuden Seura, Heikki Ojansuun arkisto (Finnish Literature Society, Heikki Ojansuu archive)) 


\section{References}

Erelt, Mati, Tiiu Erelt \& Kristiina Ross. 2020. Eesti keele käsiraamat. Uuendatud väljaanne. Tallinn: Eesti Keele Instituut, EKSA.

Ernits, Enn. 2012. Fr. R. Kreutzwald lõunaeestlaste piire kompimas. In Jüvä Sullõv (ed.). Õdagumeresoomõ piiriq (Võro Instituudi toimõndusõq 26), 30-65. Võro: Võro Instituut.

Ernits, Enn. 2018. Kraasna rahvalaulude esimestest üleskirjutustest. In Jüvä Sullõv (ed.). Valitsõmisjaotusõst keeleaoluuni (Võro Instituudi toimõndusõq 33), 157-201. Võro: Võro Instituut.

Faster, Mariko. 2015. Jumalõluuk nõssi taivadõ ehk keelesaared jälle pildil. In Mati Erelt (ed.). Emakeele Seltsi aastaraamat 60 (2014), 263-272. Tallinn: Teaduste Akadeemia Kirjastus. https://doi.org/10.3176/esa60.13.

Haak, Anu et al. 1994-2020. Eesti murrete sõnaraamat 1 (1)-7 (31). a-pari. Tallinn: Eesti Keele Instituut.

Hakulinen, Lauri. 1968. Suomen kielen rakenne ja kehitys 3., korjattu ja lisätty painos. Helsinki: Otava.

Junttila, Santeri. 2012. The prehistoric context of the oldest contacts between Baltic and Finnic languages. In A Linguistic Map of Prehistoric Northern Europe (Suomalais-Ugrilaisen Seuran toimituksia 266), 261-296. Helsinki: Suomalais-Ugrilainen Seura.

Kallas, Oskar. 1903. Kraasna Maarahvas. Helsinki: Soome Kirjanduse Selts.

Kasik, Reet. 2015. Sõnamoodustus (Eesti keele varamu 1). Tartu: Tartu Ülikooli Kirjastus.

Kettunen, Lauri. 1929. Eestin kielen äännehistoria. 2., uusittu painos (Suomalaisen Kirjallisuuden Seuran toimituksia 156). Helsinki.

Kulonen, Ulla-Maija (ed.). 1995. Suomen sanojen alkuperä. Etymologinen sanakirja 2 (Suomalaisen Kirjallisuuden Seuran toimituksia 556. Kotimaisten kielten tutkimuskeskuksen julkaisuja 62). Helsinki: Suomalaisen Kirjallisuuden Seura.

Kulonen, Ulla-Maija (ed.). 2000. Suomen sanojen alkuperä. Etymologinen sanakirja 3 (Suomalaisen Kirjallisuuden Seuran toimituksia 556. Kotimaisten kielten tutkimuskeskuksen julkaisuja 62). Helsinki: Suomalaisen Kirjallisuuden Seura.

Käsi, Inge. 2000. Levinumad adjektiivisufiksid Võru murdes. In Jüri Viikberg (ed.). Inter dialectos nominaque. Pühendusteos Mari Mustale 11. novembril 2000 (Eesti Keele Instituudi toimetised 7), 173-178. Tallinn: Eesti Keele Sihtasutus.

Käsi, Inge. 2011. Vanapärase Võru murde sõnaraamat. Rõuge, Vastseliina, Setu. Tallinn: Eesti Keele Sihtasutus.

Käsi, Inge. 2016. Seto sõnastik. Eesti Keele Instituut. http://www.eki.ee/dict/setosonastik/ (12 May, 2021).

Laanest, Arvo. 1975. Sissejuhatus läänemeresoome keeltesse. Tallinn: Eesti NSV Teaduste Akadeemia.

Mägiste, Julius. 1928. oi-, ei-deminutiivid läänemeresoome keelis. Läänemeresoome nominaaltuletus. 1 (Acta et Commentationes Universitatis Tartuensis (Dorpatensis) B XII 2 ). Tartu: Tartu Ülikool. 
Mägiste, Julius. 1982-1983. Estnisches etymologisches Wörterbuch 1-12. Helsinki: Finnisch-Ugrische Gesellschaft.

Mets, Mari, Anu Haak, Triin Iva, Grethe Juhkason, Mervi Kalmus, Miina Norvik, Karl Pajusalu, Pire Teras, Tuuli Tuisk \& Lembit Vaba. 2014. Lõunaeesti keelesaarte tekstid (Eesti murded IX). Tallinn: Eesti Keele Instituut, Tartu Ülikool.

Metsmägi, Iris, Meeli, Sedrik \& Sven-Erik Soosaar. 2012. Eesti etümoloogiasõnaraamat. Tallinn: Eesti Keele Sihtasutus.

Mund, Argo. 2005. ndus-liide eesti keeles ehk peksandusest ja pärandusest e-postinduse ja perearstinduseni. Oma Keel (1). 21-32.

Must, Mari. 2000. Vene laensõnad eesti murretes. Tallinn: Eesti Keele Sihtasutus.

Neetar, Helmi. 1990. Deverbaalne nominaaltuletus eesti murretes. 1. Tallinn: Eesti Teaduste Akadeemia Keele ja Kirjanduse Instituut.

Neus, Heinrich. 1852. Ehstnische Volklieder 3. Urschrift und Uebersetzung. Reval: Estländische literärische Gesellschaft.

Pajusalu, Karl. 2020. Lõunaeesti murded. In Tiit Hennoste (ed.), Eesti murded ja kohanimed. 3. kohendatud ja täiendatud trükk, 173-202. Tartu: Eesti Keele Sihtasutus.

Pall, Valdek. 1982-1989. Väike murdesõnastik 1-2. Tallinn: Valgus.

Saar, Eva, Paul Hagu, Inge Käsi, Maeve Leivo, Hanna Pook \& Karl Pajusalu. 2020. Seto eripäraste sõnade sõnaraamat. Tartu, Tallinn: EKSA, 2020.

Tanning, S[alme]. 1955. ng-sufiksist eesti murdeis. In Emakeele Seltsi aastaraamat 1, 128-133. Tallinn: Eesti Riiklik Kirjastus.

Univere, Aili. 1972. Eesti $t u$-liitelistest omadussõnadest. In Emakeele Seltsi aastaraamat 18 (1972), 159-173. Tallinn: Eesti Riiklik Kirjastus.

Vääri, Eduard. 2013. Sugulusalane sõnavara läänemeresoome keeltes (Töid antropoloogilise ja etnolingvistika vallast 8). Tallinn: Eesti Keele Sihtasutus.

Viires, Helmi. 1960. ne-omadussõnade tähendusrühmad eesti murretes. Emakeele Seltsi aastaraamat 6. 48-70.

Weber, Tobias. 2016. Kraasna - The state of documentation and description of an extinct South Estonian dialect. Unpublished Bachelor's thesis. Munich: LudwigMaximilians-Universität München. https://www.dropbox.com/s/d09k096k001sf62/ Arbeit_Anhang3.pdf (12 May, 2021).

Weber Tobias. 2018. On linguistic fieldnotes, legacy material, and objectivity - a case study on the meta-documentation of the South Estonian Kraasna dialect. Dissertation for the degree of MA. https://www.dropbox.com/s/tafd9h43y4v2fhh/Weber fieldnotes_legacy_material_dissertation.pdf(12 May, 2021).

Wiedemann, Ferdinand Johann. 1973. Estnisch-deutsches Wörterbuch. Eesti-saksa sõnaraamat. 4., muutmata trükk teisest, Jakob Hurda redigeeritud väljaandest. Tallinn: Valgus. 
Kokkuvõte. Enn Ernits: Kraasna noomenituletus. Vaatamata talletatud sõnavara piiratusele ilmneb Kraasna murrakus rohkesti käändsõnatuletisi. Need on moodustatud 20 primaarsufiksist tekkinud 18 liite ja 21 sekundaarsufiksist kujunenud sama arvu liidete abil. Kraasna sufiksid sarnanevad seto omadega. Ainult liitliited (-i)s-to, -la-s ja -ži-ne, mis tuletavad vaid üksikuid sõnu (kaklas, laanisto, soomisto, ammuužine), pole seto murrakutele omased. Viimatimainitud sufiks esineb ka Hargla, leivu ja lutsi murrakutes. Kraasna murrakule oli iseloomulik liidete *-ek ja *eš sarnastunud kuju -eh, seevastu seto murrakutes võivad need esineda paralleelselt $-e h$ ja $-e^{q}$ kujul. Obliikvakäändes derivatiivsufiks -eh esines XIX sajandi keskpaiku veel ühe rahvalaulu sõnas *valgõ-hõ-ta, XX sajandi alguseks oli taandunud, vrd *valgõt. Kraasna murrakus kasutati rohkesti deminutiivliidet -kanõ. Enamikul Kraasna käändsõnatuletistel on vasted seto murrakutes, üksnes vähestel juhtudel see puudub, sh kipõküüdzüs 'kurivaim', mako 'magamine', tukim 'tugi' ja vadõridz $\tilde{O}^{q}$ 'vaderid'. Teadaolevalt ainult Kraasna murrakus esinevad sõnad laudadz $\tilde{O}^{q} \sim$ laadadz $\tilde{O}^{q}$ 'lehmakahi' ja puzanõ 'mõrkjas'. Kraasna murrak, mis irdus setost XX sajandi alguse kirjapanekutega võrreldes 300 aastat varem, on viimasega üllatuslikult sarnane. Tuleks uurida, kuivõrd suutsid murrakuid ühtlustada hilisemad seosed Setomaaga.

Märksõnad: morfoloogia, käändsõnad, tuletised, läänemeresoome keeled, eesti keel, lõunaeesti keel, seto keel, Kraasna 